\title{
Insecticidal Activities of Aqueous Extracts of Five Nigerian Aromatic Spices against Garden Eggplant Defoliators and Fruit Borer Leucinodes orbonalis Guenee: Lepidoptera: Crambidae
}

\author{
Juliana A. Ugwu ${ }^{* *}$, Kehinde T. Kareem ${ }^{2}$ and Julius O. Aluko ${ }^{1}$ \\ ${ }^{1}$ Forestry Research Institute of Nigeria, P.M.B.5054, Jericho Hills, Ibadan, Oyo State, Nigeria \\ ${ }^{2}$ Institute of Agricultural Research and Training, Obafemi Awolowo University, Ile ife, Nigeria \\ Emails:dr.amaka2013@gmail.com*; kt_kareem@yahoo.com; juliwal2002@yahoo.com \\ *Corresponding author
}

Received 2 Apr 2021, Revised 26 Aug 2021, Accepted 31 Aug 2021, Published Aug 2021

DOI: https://dx.doi.org/10.4314/tjs.v47i3.39

\begin{abstract}
The study evaluated the prospects of aqueous extracts of five Nigerian spices against garden eggplant defoliators and fruit borer (Leucinodes orbonalis) in the field. The treatments consisted of Piper guineense (black pepper), Aframomum melegueta (aligator pepper), Eugenia aromatica (cloves), Zingiber officinale (ginger), Capsicum annum (chilli pepper) and untreated check (control). All the aqueous extracts evaluated reduced leaf damaged by defoliators on garden eggplant compared to control. $P$. guineense, with mean value of 11.02 number of perforations, was the most effective against defoliators, followed by E. aromatica (12.97) reducing leaf damage by 39.64 and $28.74 \%$, respectively. However, their efficacies against defoliating insects were not significantly different $(\mathrm{p}>0.05)$ among other extracts. $P$. guineense was also more effective than other spices against infestations by garden eggplant fruit borer and larvae density on fruits with mean values of 1.07 and 0.47 , respectively. Plots treated with $P$. guineense recorded highest fruit yield (629 g/plant), followed by E. aromatica (219.3 g/plant). Piper guineense and E. aromatica extracts were thus more efficacious than other spices against defoliating and fruit boring insects of garden eggplants. Adopting the applications of extracts from these spices in home garden will minimize environmental and health hazards associated chemical pesticides and enhance healthy living among the populace.
\end{abstract}

Keywords: spices, aqueous extracts, garden eggplant, Leucinodes orbonalis.

\section{Introduction}

Garden eggplant Solanaum gilo Raddi is an important vegetable crop in West, Central and East Africa (Blay and Oakes 1996). Garden eggplants are extensively cultivated throughout the tropics (Sani et al. 2004). In Nigeria, garden eggplants are cultivated for home consumption in homestead gardens as well as in commercial scales in the northern and eastern part of the country. The fruits are consumed raw as vegetable snacks by children and adults, boiled or fried for making sauces for cocoyam or yam porridge, or at times stiffed before consumption (Snowdon 1991, Onwuka 2005, Emeasor and Uwalaka 2018).

The garden eggplant is a good source of proteins, vitamins (A, B and C) calcium, potassium, magnesium and phosphorus which are very essential in the prevention and treatments of some ailments like bronchitis and asthma (Purseglove 1988, Dupriez and Deleener 1989). According to Chadha and Oluocha (2003), consumption of garden eggplant has been recommended to fight 
malnutrition problems among children within 5 years of age and child bearing age women in Africa. Apart from the nutritional values, they have cultural values in southeastern part of Nigeria where they are served alongside with kola nuts (Cola accumilata) in various ceremonial occasions such as marriages, festivals, traditional title taking and meetings (Okafor 1993).

Production of garden eggplants in Nigeria is largely constrained by pests and diseases among other factors. A large number of pests and diseases ranging from defoliators, mites stem borers, fruits borers and flower borers attack this crop in the field. In southeastern agro-ecological zone of Nigeria, fruit and shoot borer, Leucinodes orbonalis Guenée, has been identified as the major insect pest attacking the garden eggplants (Emeasor and Uwalaka 2018). The damage caused by fruit and shoot borer reduces yield and quality of the produce and consequently affect their market prices. $L$. orbonalis attacks all stages of garden eggplants in Nigeria causing severe damages at various levels (Onekutu et al. 2010).

Due to the arrays of pests and diseases associated with garden eggplants, the most widely used method of managing their pests in Nigeria is application of synthetic insecticides. However, these chemicals are highly detrimental to human health and environment, hence necessitating the search for alternative and safe pest control options. The use of various parts of indigenous plants as botanical extracts has become important in pest management in modern days due to the environmental hazards associated with the chemical control measures (Mangala and Mauria 2006, Guleria and Tiku 2009). Consequently, attention is now shifted to biopesticides from plants for pest control due to the health problems associated with synthetic pesticide residues accumulations in the plants. Several plants have been screened for their insecticidal properties and have been found effective against many insect pests of different agricultural crops ( Lengai et al. 2020). The use of biopesticides from plant materials are preferably safe, ecofriendly, biodegradable and affordable. Plant spices have been used widely in the in management of insect pests and diseases of various crops both in the stores and fields. Aqueous extracts of some spices such as Piper guineense, and Aframomum melegueta have been reported to be very effective against oriental fruit fly larvae under laboratory conditions (Ugwu and Nwaokolo 2020). Garlic extracts is reported to reduce garden eggplant borer population in the field (Emeasor and Uwalaka 2018). Essential oil of Zingiber zerumbet demonstrated repellant effects against Lasioderma serricorne (Wu et al. 2017). This study therefore evaluated the efficacy of aqueous extracts of five spices; Piper guineense Schum and Thonn (black pepper), Aframomum melegueta (Roskoe) K. Schum(aligator pepper), Zingiber officinale Roscoe ( ginger), Eugenia aromatica L.(cloves) and Capsicum annum L. (chilli pepper) against defoliators and fruit borer $L$. orbonalis on garden eggplants in the field.

\section{Materials and Methods \\ Experimental site and Land preparation}

The experiment was conducted at teaching and research farm of the Federal College of Forestry Ibadan during the planting season of 2019 between May and August. The site is located on latitude $7.9^{\circ} \mathrm{N}$ and longitude $3.5^{\circ} \mathrm{E}$ in rain forest zone of south western Nigeria. The land was manually cleared with cutlass and the debris was packed to the boundaries. Cured poultry manure was applied as a basal treatment at the rate of $15.9 \mathrm{t} / \mathrm{ha}$ and was allowed to stay for one week before making the beds.

\section{Nursery activities}

Top soils were collected at the College farm and were sieved with a sieve mesh of $2.00 \mathrm{~mm}$. The garden eggplant seeds purchased from seed shops in Ibadan were broadcasted on a nursery basket with the top soil, then wetted and covered with transparent polythene to induce heat for germination. The polythene was removed as soon as the seeds started sprouting 
and the seedlings were wetted every other day. The seedlings were attended to until 4 weeks when they were due for transplanting.

\section{Collection and preparation of extracts}

Dried fruits of West African black pepper $(P$. guineense), chilli pepper ( $C$. annum), cloves (E. aromatic) aligator pepper (A. melegueta) and tubers of ginger ( $Z$. officinale) purchased from local markets in Ibadan were further dried in an oven at $80{ }^{\circ} \mathrm{C}$ for 24 hours. The dried samples of spices were blended into powdery form using electric blender, and $200 \mathrm{~g}$ of each powdered samples were weighed into 2 liters bottles separately. One liter of warm water $(60$ ${ }^{\circ} \mathrm{C}$ ) was poured into each bottle containing the powder. The mixture was vigorously shaken at intervals for 45 minutes and then covered airtight and left to stand for 24 hours. Then extracts were filtered with muslin cloth to obtain a homogenous mixture. To each extract mixture, dish washing soap solution $(10 \mathrm{ml})$ was added to improve on their spread and adherence to the plants.

\section{Field establishments and treatment applications}

Individual plots consisted of three rows, $2 \times 1.5$ $\mathrm{m}$ apart, $1 \mathrm{~m}$ unplanted barrier separated each plot. Four weeks old of garden eggplant seedlings were transplanted to field at the spacing of $30 \times 45 \mathrm{~cm}$ at the rate of one seedling per stand with 8 seedlings per a bed /roll. The experimental layout was a Randomized Block Design (RBD) in three replications consisting of six treatments $[(P$. guineense, $C$. annum, $Z$. officinale, $E$. aromatica, A. melegueta aqueous extracts and untreated check (control)]. All the aqueous extracts were applied at $200 \mathrm{~g} / \mathrm{L}$ with Harry hand sprayer. Spraying for each treatment commenced at four weeks after transplanting (4WAT) between 9.00 am and 11.00 am at two weeks intervals.

\section{Assessments of leaf and fruit damage}

Leaf damage by defoliators was assessed through sampling 5 selected and tagged plants from each plot for number of perforations on the leaves weekly. A fruit was considered damaged when it had feeding scars, frass or emergent hole on it. The damaged fruits were dissected and examined for presence of fruit borer larvae. The number of larvae per damaged fruits were counted and recorded accordingly. Percentage leaf damage was calculated using the formula

$$
\text { PLD }=\frac{\text { NPTP }}{\text { TPAL }} \times 100
$$

where PLD is percentage leaf damage, NPTP is number of perforation per each treated plot and TPAL is total number of perforations on all assessed leaves.

\section{Data analysis}

Data collected were subjected to Analysis of Variance (ANOVA) and significant means were separated using Turkey`s Honestly Significant Difference (HSD).

\section{Results \\ Effects of the treatments on leaf damage by defoliators}

The results on the assessments of the effects of treatments against insect defoliators are presented in Table 1. The results revealed that all the treatments were effective in reducing the damage by insect defoliators on the leaves compared to untreated plot. Three defoliating insects (Acraea sp, Zonocerus variegatus and Eulioptera $s p$ ) were observed causing leaf damage on Garden eggplants. Plots treated with $P$. guineense extract recorded the least number of perforations on the leaves with mean value of 11.02 after 13 weeks reducing leaf damage by $39.64 \%$ compared to control. Plots treated with $E$. aromatica extract with mean value of 12.97 number of perforations followed by $P$. guineese extract which had mean value of 11.02, the former indicating effectiveness in reducing leaf damage by $28.74 \%$ compared to the control. However, there were no significant differences $(p>0.05)$ among the extracts of plants on their efficacies against leaf defoliators of garden eggplants. Control plots recorded highest number of defoliation (18.20) 
with $21.24 \%$ leaf damage. Plots treated with $P$. guineese and E. aromatica extracts showed significant differences $(p<0.05)$ on their efficacy against leaf defoliators of garden eggplant compared to control plot. The weekly assessment on the number of perforations on garden eggplant leaves by defoliator implies damages done by defoliators were higher at the earlier weeks (1-4) of the study, hence weeks of the plant growth (Figure 1). A similar trend was observed in all the plots treated by different aqueous extracts.

Table 1: Effects of the treatments on leaf damage of garden eggplants by defoliators

\begin{tabular}{|c|c|c|c|c|}
\hline \multirow[t]{2}{*}{ Treatments } & \multirow{2}{*}{$\begin{array}{l}\text { Mean number of } \\
\text { perforation/plant }\end{array}$} & \multirow{2}{*}{$\begin{array}{l}\text { Percentage } \\
(\%) \quad \text { leaf } \\
\text { damage }\end{array}$} & \multirow{2}{*}{$\begin{array}{l}\text { Percentage }(\%) \text { leaf } \\
\text { damage compared } \\
\text { to control }\end{array}$} & \multirow{2}{*}{$\begin{array}{l}\text { Percentage reduction } \\
\text { of leaf damage } \\
\text { compared to control }\end{array}$} \\
\hline & & & & \\
\hline P. guineense & $11.02^{\mathrm{b}}$ & $12.86^{\mathrm{b}}$ & 60.54 & 39.64 \\
\hline A. melegueta & $15.13^{\mathrm{ab}}$ & $17.66^{\mathrm{ab}}$ & 83.13 & 16.87 \\
\hline E. aromatica & $12.97^{\mathrm{b}}$ & $15.14^{\mathrm{b}}$ & 71.26 & 28.74 \\
\hline Z. officinale & $14.16^{\mathrm{ab}}$ & $16.53^{\mathrm{ab}}$ & 77.80 & 22.20 \\
\hline C. аппиит & $14.19^{\mathrm{ab}}$ & $16.56^{\mathrm{ab}}$ & 77.97 & 22.02 \\
\hline Control & $18.20^{\mathrm{a}}$ & $21.24^{\mathrm{a}}$ & 100 & 100 \\
\hline
\end{tabular}

Means with the same superscript letters within the same column do not differ statistically $(\mathrm{P}<$ 0.05 ) by Turkey`s Honestly Significant Difference (HSD).

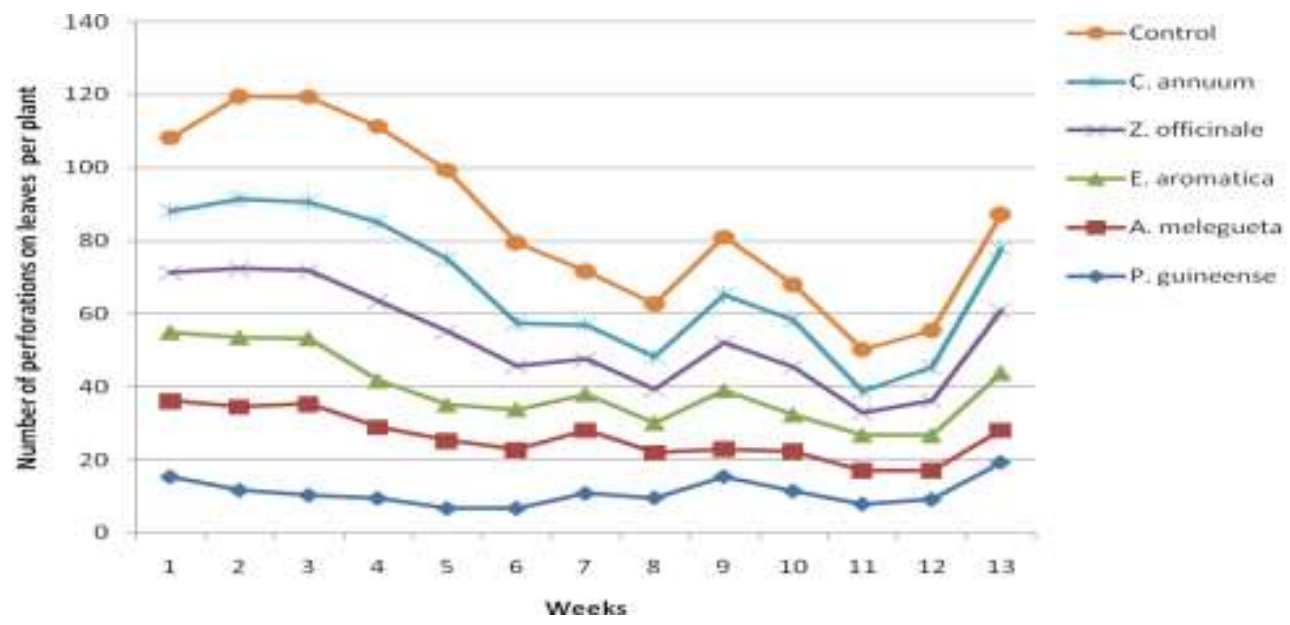

Figure 1: Mean number of perforations on leaves per garden eggplants over time.

Effects of the treatments on the number of damaged fruits by Leucinodes orbonalis

The results on the evaluation of the effect of treatments on the number of damaged fruits by $L$. orbonalis are shown in Table 2 . The results revealed that all the treatments relatively reduced damages by Leucinodes orbonalis compared to the control. There were no significant differences ( $\mathrm{p}>0.5)$ among all the treatments on the number of infested fruits by $L$. orbonalis. However, the least number of infested fruits were recorded on plots treated with $P$. guineense extract with mean value of 1.07 per plant, followed by those treated with extract from $Z$. officinale that had mean value of 1.09 per plant. There were no significant differences $(p>0.05)$ on effects of the various treatments on the mean numbers of infected fruits between all the extracts and the control. 
Ugwu et al. - Insecticidal Activities of Aqueous Extracts of Five Nigerian Aromatic Spices ...

Table 2: Effects of the treatments on the number of infested fruits

\begin{tabular}{|c|c|c|c|c|c|c|c|c|c|c|c|}
\hline \multirow[t]{2}{*}{ Treatments } & \multicolumn{11}{|l|}{ Weeks } \\
\hline & 1 & 2 & 3 & 4 & 5 & 6 & 7 & 8 & 9 & 10 & Mean \\
\hline P. guineense & $0.00^{\mathrm{bc}}$ & $1.33^{\mathrm{b}}$ & $0.67^{\mathrm{ab}}$ & $0.67^{\mathrm{ab}}$ & $2.33^{\mathrm{ab}}$ & $0.33^{\mathrm{c}}$ & $2.67^{\mathrm{a}}$ & $0.67^{\mathrm{bc}}$ & $167^{\mathrm{ab}}$ & $0.33^{\mathrm{ab}}$ & $1.07^{\mathrm{a}}$ \\
\hline A. & $0.00^{\mathrm{bc}}$ & $0.33^{\mathrm{c}}$ & $0.67^{\mathrm{ab}}$ & $1.00^{\mathrm{ab}}$ & $3.00^{\mathrm{a}}$ & $2.00^{\mathrm{ab}}$ & $1.33^{\mathrm{ab}}$ & $0.67^{\mathrm{bc}}$ & $1.00^{\mathrm{b}}$ & $1.67^{\mathrm{a}}$ & $1.17^{\mathrm{a}}$ \\
\hline Melegueta & & & & & & & & & & & \\
\hline $\begin{array}{l}\text { E. } \\
\text { aromatica }\end{array}$ & $1.00^{\mathrm{a}}$ & $1.00^{\mathrm{b}}$ & $0.67^{\mathrm{ab}}$ & $1.33^{\mathrm{ab}}$ & $0.00^{c}$ & $0.67^{\mathrm{bc}}$ & $1.00^{\mathrm{ab}}$ & $2.00 \mathrm{a}$ & $1.67^{\mathrm{ab}}$ & $1.67^{\mathrm{a}}$ & $1.10^{\mathrm{a}}$ \\
\hline Z. officinale & $0.00^{\mathrm{bc}}$ & $2.33^{\mathrm{ab}}$ & $0.67^{\mathrm{ab}}$ & $1.67^{\mathrm{ab}}$ & $0,67^{\mathrm{c}}$ & $1.00^{\mathrm{abc}}$ & $1.67^{\mathrm{ab}}$ & $1.33^{\mathrm{b}}$ & $1.00 \mathrm{~b}$ & $0.33^{\mathrm{ab}}$ & $1.09^{\mathrm{a}}$ \\
\hline C. аппиит & $0.67^{\mathrm{ab}}$ & $0.67^{\mathrm{bc}}$ & $0.00^{\mathrm{b}}$ & $2.00^{\mathrm{a}}$ & $0.67^{c}$ & $1.33^{\mathrm{abc}}$ & $1.00^{\mathrm{ab}}$ & $1.67^{\mathrm{ab}}$ & $2.33^{\mathrm{a}}$ & $1.67^{\mathrm{a}}$ & $1.20^{\mathrm{a}}$ \\
\hline Control & $0.33^{\mathrm{b}}$ & $3.00^{\mathrm{a}}$ & $1.33^{\mathrm{a}}$ & $2.00^{\mathrm{a}}$ & $1.33^{\mathrm{bc}}$ & $2.33^{\mathrm{a}}$ & $0.67^{\mathrm{b}}$ & $1.67^{\mathrm{ab}}$ & $1.67^{\mathrm{ab}}$ & $1.33^{\mathrm{a}}$ & $1.33^{\mathrm{a}}$ \\
\hline
\end{tabular}

Means with the same superscript letters within the same column do not differ statistically $(\mathrm{P}<$ $0.05)$ by Turkey`s Honestly Significant Difference (HSD).

\section{Effects of the treatments on the population of Leucinodes orbonalis}

The results on the effects of the various treatments on the population of $L$ orbonalis revealed that all the aqueous extracts of the spices significantly $(\mathrm{p}<0.05)$ reduced invasion by L. orbonalis compared to the control (Table 3). Plots treated with $P$. guineense extract had the least number of $L$. orbonalis larvae with mean value of 0.47 . Control plots recorded highest number of $L$. orbonalis larvae with mean value of 0.80 . P. guineense extracts significantly $(\mathrm{p}<0.5)$ reduced the population of $L$. orbonalis by $50 \%$, while other extracts uniformly reduced $L$. orbonalis population by only $8.75 \%$ compared to the control during the experimental period.

Table 3: Effects of the treatments on the population of garden eggplant fruit borer larvae

\begin{tabular}{|c|c|c|c|c|c|c|c|c|c|c|c|}
\hline \multirow[t]{2}{*}{ Treatments } & \multicolumn{11}{|l|}{ Weeks } \\
\hline & 1 & 2 & 3 & 4 & 5 & 6 & 7 & 8 & 9 & 10 & Mean \\
\hline $\begin{array}{l}P . \\
\text { guineense }\end{array}$ & $0.00^{\mathrm{b}}$ & $0.67^{\mathrm{ab}}$ & $0.67^{\mathrm{ab}}$ & $1.00^{\mathrm{ab}}$ & $0.33^{\mathrm{b}}$ & $0.33^{\mathrm{c}}$ & $0.67^{\mathrm{b}}$ & $0.33^{\mathrm{bc}}$ & $0.67^{\mathrm{ab}}$ & $0.00^{\mathrm{c}}$ & $0.4^{\mathrm{b}}$ \\
\hline $\begin{array}{l}\text { A. } \\
\text { Melegueta }\end{array}$ & $0.33^{\mathrm{ab}}$ & $1.00^{\mathrm{a}}$ & $1.33^{\mathrm{a}}$ & $0.00^{\mathrm{b}}$ & $0.67^{\mathrm{ab}}$ & $1.67^{\mathrm{a}}$ & $0.67^{\mathrm{b}}$ & $1.67^{\mathrm{a}}$ & $1.00^{\mathrm{ab}}$ & $0.67^{\mathrm{ab}}$ & $0.73^{\mathrm{ab}}$ \\
\hline $\begin{array}{l}\text { E. } \\
\text { aromatica }\end{array}$ & $0.67^{\mathrm{a}}$ & $0.33^{\mathrm{b}}$ & $0.67 \mathrm{ab}$ & $1.67^{\mathrm{a}}$ & $0.00^{\mathrm{b}}$ & $0.67^{\mathrm{b}}$ & $0.67^{\mathrm{b}}$ & $1.00^{\mathrm{ab}}$ & $1.00^{\mathrm{ab}}$ & $0.67^{\mathrm{ab}}$ & $0.73^{\mathrm{ab}}$ \\
\hline $\begin{array}{l}Z . \\
\text { officinale }\end{array}$ & $0.00^{\mathrm{b}}$ & $0.33^{\mathrm{b}}$ & $0.67^{\mathrm{ab}}$ & $0.33^{\mathrm{b}}$ & $1.00^{\mathrm{ab}}$ & $0.33^{c}$ & $0.33^{\mathrm{b}}$ & $0.33^{\mathrm{bc}}$ & $0.67^{\mathrm{b}}$ & $0.33^{\mathrm{b}}$ & $0.73^{\mathrm{ab}}$ \\
\hline C. апnиum & $0.33^{\mathrm{ab}}$ & $0.33^{\mathrm{b}}$ & $0.00^{\mathrm{b}}$ & $1.00^{\mathrm{ab}}$ & $0.67^{\mathrm{ab}}$ & $1.00^{\mathrm{b}}$ & $0.67^{\mathrm{b}}$ & $0.67^{b}$ & $1.67^{\mathrm{a}}$ & $1.00^{\mathrm{a}}$ & $0.73^{\mathrm{ab}}$ \\
\hline Control & $0.00^{\mathrm{b}}$ & $0.33^{\mathrm{b}}$ & $0.67^{\mathrm{ab}}$ & $0.33^{\mathrm{b}}$ & $2.00^{\mathrm{a}}$ & $1.33^{\mathrm{ab}}$ & $1.67^{\mathrm{a}}$ & $1.00^{\mathrm{ab}}$ & $0.67^{\mathrm{b}}$ & $1.00^{\mathrm{a}}$ & $0.80^{\mathrm{a}}$ \\
\hline
\end{tabular}

Means with the same superscript letters within the same column do not differ statistically (P < $0.05)$ by Turkey`s Honestly Significant Difference (HSD).

Effects of the treatments on the yields of garden eggplants

The results on the effects of different treatments on the yields of garden eggplants revealed that different treatments enhanced fruit yield compared to the control (Table 4). Plots treated with $P$. guineense extract significantly $(\mathrm{p}<0.05)$ recorded the highest yield of garden eggplant fruits with mean value of $639 \mathrm{~g} /$ plant fresh weight compared to other plant extracts. This was followed by plots treated with E. aromatica extract which had a mean value of $217.33 \mathrm{~g} / \mathrm{plant}$ in yield of garden eggplant fruits. Control plots recorded the least yield of garden eggplant fruits with mean value of $125 \mathrm{~g} / \mathrm{plant}$. There was significant difference $(\mathrm{p}<0.05)$ between the yields of garden eggplants recorded on plots treated with the various extracts and the control plots. The best protection was observed on 
plots treated with extracts of $P$. guineense followed by the plots treated with $E$ aromatica extract. Plots treated by these two extracts also gave higher fruit yields than plots treated with A. melegueta, $Z$. officinale and $C$. annuum extracts. The untreated check (control) plots gave the lowest yield at the end of the study period. The aqueous extracts of $P$. guineense enhanced the fruit yield of garden eggplants by $34.62 \%$ compared to control plots. The weekly yield of garden eggplants increased over time and decline toward the end of the experiments (Figure 2). The peak of the fruit yields was observed between the fifth and sixth weeks on all the treated plots including control plots during this study.

Table 4: Effects of the treatments on the yields of garden eggplant fruits

\begin{tabular}{llll}
\hline Treatments & Mean yield $(\mathrm{g})$ & $\begin{array}{l}\text { Percentage } \\
(\%) \text { yield }\end{array}$ & $\begin{array}{l}\text { Percentage }(\%) \text { increased yield } \\
\text { compared to control }\end{array}$ \\
\hline P. guineese & $639.00^{\mathrm{a}}$ & 43.14 & 34.62 \\
A. Melegueta & $162.00^{\mathrm{b}}$ & 10.94 & 2.42 \\
E. aromatica & $217.33^{\mathrm{b}}$ & 14.67 & 6.15 \\
Z. officinale & $176.33^{\mathrm{b}}$ & 11.90 & 3.38 \\
C. annuum & $160.33^{\mathrm{b}}$ & 10.82 & 2.3 \\
Control & $126.33^{\mathrm{c}}$ & 8.52 & 0 \\
\hline
\end{tabular}

Means with the same superscript letters within the same column do not differ statistically (P < $0.05)$ by Turkey`s Honestly Significant Difference (HSD).

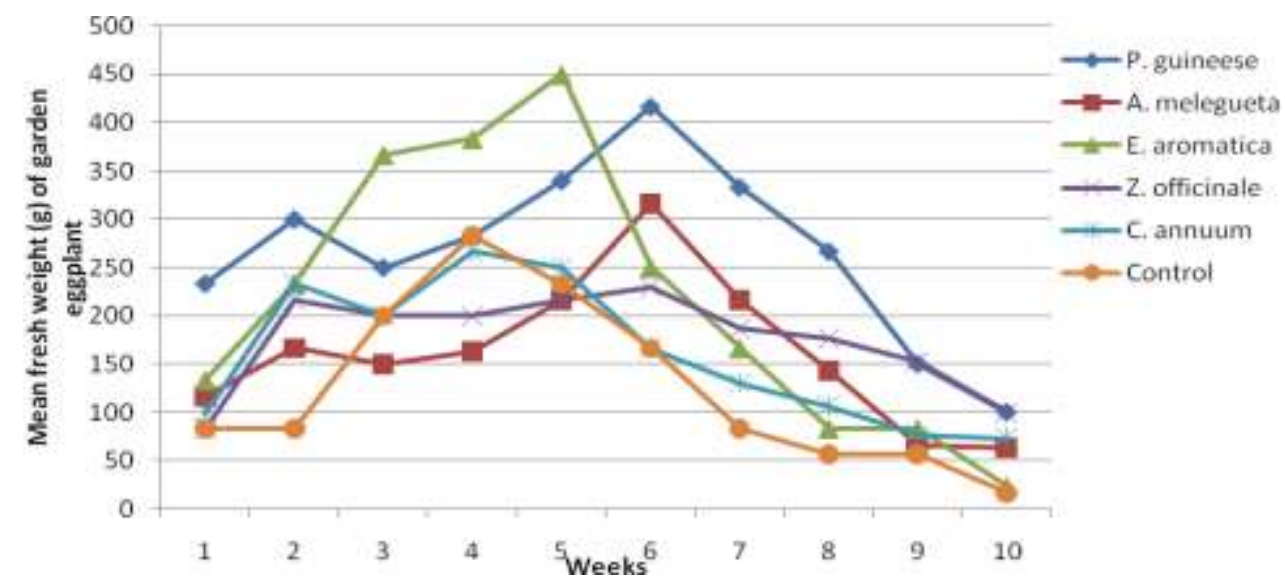

Figure 2: Weekly yield of garden eggplants per plant over ten weeks' time.

\section{Discussion}

The study has demonstrated the potential of the tested plant extracts to lessen garden eggplant leaf damage by defoliators and decimate populations of $L$ orbinalis larvae. All the aqueous extracts of the spices evaluated reduced the number of perforations by defoliators on leaves, fruit damage and density of $L$ orbonalis larvae on fruits of the garden eggplants. These findings support earlier reports that extracts from aromatic plants possess insecticidal, antifeedants, ovicidal oviposition inhibitors and growth reducing effects on several insect species (Sithisut et al. 2011, Regnault-Roger et al. 2012). Emeasor and Uwalaka (2018) also reported that different concentrations of ethanolic extracts of garlic were found efficacious against insect pests of garden eggplants. Similarly, aqueous extracts of $P$. guineense, A. melegueta, X. aethiopica, $Z$. 
officinale and $C$. annuum were reported to be potent against Maruca vitrata and Clavigralla tomentosicollis of cowpea (Oparaeke et al. 2005). P. guineense extract was most effective than other extracts in protecting garden eggplants against defoliators (Acraea $s p$, Zonocerus variegatus and Eulioptera $s p$ ) and fruit borer (L. orbonalis) in this study. These results corroborate the earlier findings by Fasaki and Aberejo (2002) who reported that pulverized plant materials from $P$. guineense inhibited egg hatchability and adult emergence of Dermestes maculatus DeGeer in smoked catfish (Clarias gariepinus Burchell) during storage. Correspondingly, Echereobia et al. (2010) accounted that ten percent (10\%) aqueous extracts of $P$. guineense demonstrated high repellency potentials against Podagrica species on okra Likewise, application of $P$. guineense powder was found to be effective against cowpea beetles by causing adult mortality and suppressing adult female oviposition (Idoko and Adesina 2012). Ugwu (2020) also reported that petroleum ether extract of $P$. guineense was found effective against Maruca vitrata and Megalurothrips sjostedti on cowpea in the field.

Furthermore, application of the aqueous extracts of different spices enhanced garden eggplant fruit yields in this study. The results agreed with the observations by Emeasor and Uwalaka (2018) who reported that ethanolic extract of garlic increased fruit number and fruit yields of garden egg plants. Adedire and Lajide (1999) also reported that plant materials when applied for pest control increased yields of the crop.

Field observations indicated that the aqueous extracts of the screened plants were not phytotoxic to the garden eggplant leaves and fruits. This observation supports the findings by Oparaeke et al. (2005) who reported that phytotoxicity was not observed on cowpea plants when sprayed with aqueous extracts of five Nigerian spices. Similarly, Emeasor and Uwalaka (2018) reported that phytotoxic effects were not observed on garden eggplant when treated with ethanolic extract of garlic.

\section{Conclusion}

The results presented in this study have shown that aqueous extracts of plant spices evaluated have great potentials as biopesticides and could provide suitable alternatives for pest control on field crops of small scale and low-input agriculture as commonly practiced in tropical countries without degrading the environment. $P$. guineense and A. melegueta extracts proved more efficacious against garden eggplant leaf defoliators (Acraea sp, Zonocerus variegatus and Eulioptera $s p$ ) and fruit borer ( $L$. orbonalis) than extracts of other spices. However, further studies are necessary to elucidate the effects of various concentrations and optimum spraying conditions for $P$. guineense and A. melegueta extracts to discover the most effective combination of concentrations and spraying that would offer adequate protection to garden eggplant fruits and foliage.

Acknowledgements: Authors are grateful to the Federal College of Forestry Ibadan, Forestry Research Institute of Nigeria for provision of facilities used in this study.

Declaration of interest: Authors declare no competing interest.

\section{References}

Adedire CO and Lajide L 1999 Toxicity and oviposition deterrence of some plant extracts on cowpea storage bruchid Callosobrochus maculatus Fabricius. J. Plant Dis. Prot. 106: 647-653.

Blay E and Oakes JV 1996 Agribacterium tumefaciens mediated transformation of Solanum gilo Raddi is influenced by explants type. Plant Cell Rep. 15: 582-585.

Chadha ML and Oluoch MO 2003 Home-based vegetable gardens and other strategies to overcome micronutrient malnutrition in developing countries. Food Nutr. Agric. J. 32(1):17-23.

Dupriez H and Deleener P 1989 Vegetable and condiment Fruits. In African Gardens and 
orchards. McMillan Publishers and CTANetherlands. p. 322.

Echereobia CO, Okerere CS and Emeaso KC 2010 Determination of repellence potentials of some aqueous plant extracts against okra flea beetles Podagrica uniforma. J. Biopestic. 3(2): 505-507.

Emeasor KC and Uwalaka OA 2018 Control of fruit borer of garden egg Leucinodes orbonalis (Lepidoptera: Pyralidae) using organic and inorganic pesticides. Net J. Agric. Sci. 6(2): 1619.

Fasaki EA and Aberejo BA 2002 Effect of some pulverized plant materials on the developmental stages of fish beetle, Dermestes maculatus Degeer in smoked catfish (Clarias gariepinus) during storage. Biores. Technol. 85: 173-177.

Guleria S and Tiku TK 2009 Botanicals in Pest Management: Current Status and Future Perspectives, In: Peshin R, Dhawan AK (Eds.), Integrated Pest Management: InnovationDevelopment Process, C Springer Science+Business Media B.V.

Idoko JE and Adesina J M 2012 Evaluation of the powder of Piper guineense and pirimiphosmethly $\mathrm{F}$ for the control of cowpea beetle Callosobruchus maculatus (F.). J. Agric. Technol. 8(4): 1365-1374.

Lengai GM, Muthomi JW and Mbega ER 2020 Phytochemical activity and role of botanical pesticides in pest management for sustainable agricultural crop production. Sci. Afr. 7: e00239.

Mangala R and Mauria S 2006 Handbook of Agriculture Fact and Figure for teacher, students and all interested farmers. Indian Council of Agricultural Research, New Delhi. 1346 pp.

Okafor JC 1993 Horticulturally promising indigenous wild plant species of Nigeria Forest Zone. J. Agric. 12(7): 165-176.

Onekutu A, Omoloye AA and Odebiyi JA 2010 Severity of Leucinodes orbonalis Guenee attack on Solanum gilo Raddi in Ibadan, Southwest Nigeria. Niger. J. Plant Prot. 24: 131-135.

Onwuka G I 2005 Food analysis and instrumentation: theory and practice. Naphathali Prints, Nigeria, 95-96
Oparaeke AM, Dike MC and Amatobi CI 2005 Field evaluation of extracts of five Nigerian spices for control of post-flowering insect pests of cowpea, Vigna unguiculata (L.) Walp. Plant Protect. Sci. 41: 14-20.

Purseglove JW 1988 Tropical Crops. Dichotyledons. Longman Publishers London. pp. 557-559.

Regnault-Roger C, Vincent C and Arnason JT 2012 Essential oils in insect control: Low-risk products in a high-stakes world. Ann. Rev. Entomol. 57: 405-424.

Sani YA, Abubakar IU, Jaliya MN and Guiginyu B 2004 Growth and yield of garden egg (Solanum gilo) as affected by intra-row spacing nitrogen and phosphorus fertilizer. Proceedings of the $22^{\text {nd }}$ Annual Conference of Horticultural Society of Nigeria. pp. 37-42.

Sithisut D, Fields PG and Chandrapathya A 2011 Contact toxicity, feeding reduction and repellency of essential oils from three plants from the ginger family (Zingiberaceae) and their major components against Sitophilus zeamais and Tribolium castaneum. J. Econ. Entomol. 104: 1445-1454.

Snowdon AL 1991 A colour atlas of post harvest diseases and disorders of fruits and vegetable. Vol. 2: Vegetables. Wolf Scientific Ltd 53-94.

Ugwu JA and Nwaokolo VM 2020 Biocidal activity of selected botanicals and Beauveria bassiana on oriental fruit fly, Bactrocera dorsalis (Diptera; Tephritidae). J. Res. For. Wildl. Environ. 12: 53-61.

Ugwu JA 2020 Insecticidal activity of some botanical extracts against legume flower thrips and legume pod borer on cowpea Vigna unguiculata L. Walp. J. Basic Appl. Zool. 81:13.

WuY, Guo S, Huang D, Wang C, Wei J, Li Z, Sun JS, Bai JF, Tian ZF, Wang PJ and Du S 2017 Contact and repellant activities of zerumbone and its analogues from the essential oil of Zingiber zerumbet (L.) Smith against Lasioderma serricorne. J. Oleo Sci. 66(4): 399405. 